\title{
LATIHAN OTOT DASAR PANGGUL EFEKTIF UNTUK MENGATASI INKONTINENSIA URIN PADA KLIEN POST OPERASI PROSTATECTOMY
}

\section{Jurnal Keperawatan dan Pemikiran IImiah}

Sulistyaningsih, D (2015). Latihan Otot Dasar Panggul Efektif untuk MEngatasi Inkontinensia Urin pada Klien Post Operasi Prostatectomy. Nurscope. Jurnal Keperawatan dan

Pemikiran Ilmiah. 1 (3). 1-7

\author{
Dwi Retno Sulistyaningsih \\ Fakultas IImu Keperawatan, Universitas Islam Sultan Agung
}

\begin{abstract}
ABSTRAK
Inkontinensia urin didefinisikan sebagai suatu kondisi di mana terjadi kehilangan urin tanpa disengaja melalui meatus uretra yang dapat berakibat pada masalah sosial dan kebersihan. Inkontinensia urin dapat menyebabkan kelemahan dan biaya individu menjadi mahal, berpotensi menimbulkan persepsi yang rendah terhadap status kesehatan, harga diri rendah, malu, mengganggu hubungan antar manusia dan seksualitas, distress psycologi, mengurangi kemampuan, menjadi beban keluarga. Pada akhirnya kualitas hidup dapat terganggu. Latihan otot dasar panggul dapat memperbaiki kemampuan berkemih dengan resiko yang lebih kecil. Otot dasar panggul mendukung isi abdomen, aktif selama pernafasan, mempertahankan untuk inkontinensia urin dan feces, meningkatkan aliran darah, dan aktif selama hubungan seksual. Latihan ini juga membawa oksigen dalam aliran darah menuju area panggul untuk mempertahankan kesehatan jaringan dan mempertahankan fungsi normal. Latihan dasar otot panggul selain bermanfaat dari aspek fisiologis juga memberikan dampak bagi aspek ekonomi dan waktu yaitu untuk mengurangi keluhan berkemih sehingga pasien dapat pulang lebih cepat. Hal ini dapat mengurangi waktu dan biaya perawatan di rumah sakit.
\end{abstract}

Kata kunci : latihan otot dasar panggul, inkontinensia, prostatectomy

\begin{abstract}
Urinary incontinence is defined as a condition where an accidental loss of urine through the urethral meatus may result in social and hygiene problems. Urinary incontinence can cause weakness and the cost of the individual to be expensive, potentially cause a low perception of the health status, low self esteem, embarrassment, disrupt human relationships and sexuality, psycologi distress, reduced ability, a burden on the family. In the end the quality of life can be disrupted. Pelvic floor muscle exercises can improve the ability to urinate with lower risk. Pelvic floor muscles support the abdominal contents, active during the respiratory, urinary incontinence and to retain feces, increase blood flow, and active during sexual intercourse. This exercise also carries oxygen in the blood flow to the pelvic area to maintain tissue health and maintaining normal function. Pelvic floor exercises muscles than beneficial physiological aspects also have an impact on the economic aspects and the time is to reduce voiding complaints so that the patient can go home sooner. This can reduce the time and cost of hospital care.
\end{abstract}

Keywords: pelvic floor muscle exercises, incontinence, prostatectomy

Corresponding Author :

Dwi Retno Sulistyaningsih, Dosen Fakultas IImu Keperawatan Departemen Keperawatan Medikal BedahUniversitas Islam Sultan Agung, Jalan Raya Kaligawe Km 4, Semarang, Jawa Tengah, Indonesia, Kode pos 50112 ;e-mail : retno_fik@yahoo.com

\section{PENDAHULUAN}

Inkontinensia urin didefinisikan oleh International Continence Society (ICS) sebagai suatu kondisi di mana terjadi kehilangan urin tanpa disengaja melalui meatus uretra yang dapat berakibat pada masalah sosial dan kebersihan yang dapat diobservasi(Black, J.M.\&Hawks, 2005). Terdapat tiga type inkontinensia yaitu inkontinensia stress yang merupakan kehilangan urin tanpa disadari yang terjadi secara tiba - tiba akibat beberapa aktivitas seperti tertawa, bersin, batuk. Urge inkontinensia yaitu kehilangan urin tanpa disadari yang didahului keiginan yang kuat untuk berkemih yang tidak dapat 
dicegah. Mixed inkontinencia merupakan gabungan antara inkontinensia stress dan urge inkontinensia (Munn Zachary, 2008).

Inkontinensia dapat terjadi pada pasien dengan kanker prostat dan hyperplasia prostat hypertrofi ( BPH ). Kanker prostat merupakan keganasan yang terjadi pada laki - laki di United Kingdom dengan lebih dari 24.700 kasus baru dan 9000 orang meninggal dunia. Di Inggris dan Wales angka kejadian 54,2 per 100 populasi laki- laki semua usia yang dilaporkan serta 1 dari 10 meninggal di Eropa dan Amerika Utara. Angka kejadiannya meningkat sesuai dengan peningkatan usia. Lebih dari 17 juta orang dewasa di Amerika Serikat diperkirakan mengalami inkontinensia urin (Smeltzer, S.C., 2009)

Inkontinensia urin dapat menyebabkan kelemahan dan biaya individu menjadi mahal, berpotensi menimbulkan persepsi yang rendah terhadap status kesehatan, harga diri rendah, hubungan antar manusia dan juga aspek seksualitas yang terganggu, dan distress psycologi. Laki - laki dengan inkontinensia cenderung mengalami berbagai masalah, enggan mencari pertolongan, hidup mereka benar - benar terancam. Klien dengan inkontinensia urin juga mengurangi kemampuan klien tersebut, menjadi beban keluarga serta klien merasa malu. Keluhan - keluhan tersebut merupakan sumber - sumber signifikan yang mengurangi kualitas kehidupan. Satu dari lima klien yang mengalami inkontinensia urin cuti karena masalah tersebut dan terbatasnya pilihan tindakan. Klien mendiskusikan masalah tersebut dengan dokter seringkali tidak menjawab dan tidak memberikan alternatif tindakan konservatif.

Penanganan inkontinensia urin bergantung pada faktor penyebab yang mendasarinya. Namun demikian, sebelum terapi yang tepat dapat dimulai, munculnya masalah ini harus diidentifikasi dahulu dan kemungkinan keberhasilan terapi dapat dicapai. Jika perawat dan petugas kesehatan lainnya menerima inkontinensia sebagai bagian yang tidak terelakkan dari proses penuaan dan perjalanan penyakitnya atau menganggap inkontinensia tidak dapat dipulihkan dan tidak dapat diterapi pada usia berapapun, maka keadaan tersebut tidak akan dapat diterapi dengan hasil yang lebih baik. Upaya yang bersifat interdisipliner dan kolaboratif sangat penting dalam mengkaji dan mengatasi inkontinensia urin secara efektif (Smeltzer, S.C., 2009)

Penanganan yang pertama kali dilakukan adalah dengan meminimalkan tindakan invasif. Banyak terapi yang bertujuan untuk memperbaiki inkontinensia dapat dilakukan tanpa resiko bagi klien. Keberhasilan bergantung pada motivasi, kemampuan dan kemauan untuk melaksanakannya. Pembedahan hanya dilakukan pada saat ditemukan kelainan struktur atau anatomi(Black, J.M.\&Hawks, 2005). Penatalaksanaan inkontinensia urin meliputi intervensi pelvic floor exercise and behaviour, terapi obat-obatan dan pembedahan.

Behavioral terapi adalah pilihan pertama untuk mengurangi atau mengatasi inkontinensia urin. Dalam penggunaan cara - cara tersebut, perawat profesional membantu pasien menghindari efek merugikan dari penggunaan obat - obatan atau tindakan pembedahan. Latihan otot dasar panggul atau yang disebut Kegel exercise menggambarkan dasar behavioral terapi untuk memusatkan pada keluhan dari stress, urge, dan mixed incontinencia(Smeltzer, S.C., 2009). 


\section{PEMBAHASAN}

Otot dasar panggul pada laki - laki mempunyai banyak fungsi. Otot dasar panggul mendukung isi abdomen, aktif selama pernafasan, mempertahankan untuk inkontinensia urin dan feces, meningkatkan aliran darah, dan aktif selama hubungan seksual. Latihan ini juga membawa oksigen dalam aliran darah menuju area panggul untuk mempertahankan kesehatan jaringan dan mempertahankan fungsi normal. Latihan dasar otot panggul selain bermanfaat dari aspek fisiologis juga memberikan dampak bagi aspek ekonomi dan waktu yaitu untuk mengurangi keluhan berkemih sehingga pasien dapat pulang lebih cepat. Hal ini dapat mengurangi waktu dan biaya perawatan di rumah sakit. Tingkatan kekuatan otot dasar panggul terbagi menjadi 6 tingkat yaitu 0 tidak ada kontraksi otot, 1 flicker ( kejapan ) yaitu otot berkejap, 2 kelemahan yaitu kontraksi lemah tanpa pergerakan, 3 moderate yaitu moderate kontraksi dengan pergerakan, 4 bagus yaitu kontraksi bagus melawan tahanan, 5 kuat yaitu kontraksi kuat melawan tahanan yang kuat, sedangkan 6 sangat kuat yaitu sangat kuat tekanan erat rapat pada jari tangan pemeriksa.

Latihan otot dasar panggul atau dikenal dengan Kegel exercise pertama kali dikenalkan oleh dr. Arnold Kegel pada tahun 1940, yang dianjurkan pada klien sebagai metoda untuk mengatasi inkontinensia urin. Dr. Kegel melaporkan penurunan keluhan pada inkontinensia urge dan inkontinensia stress dengan melakukan latihan otot dasar panggul setiap hari. Lebih dari setahun, dokter menganjurkan klien untuk melakukan latihan otot dasar panggul sebagai langkah pertama untuk mengatasi inkontinensia urin. Latihan otot dasar panggul direkomendasikan oleh International Continence Society sebagai langkah pertama untuk mengatasi inkontinensia urin. Latihan otot dasar panggul dapat memperbaiki kemampuan berkemih dengan resiko yang lebih kecil(Black, J.M.\&Hawks, 2005). Latihan otot dasar panggul memberikan pengaruh baik terhadap tingkat kemampuan fisik manusia bila dilaksanakan dengan tepat dan terarah. Klien harus menyadari dan termotivasi untuk melakukannya serta melanjutkan penggunaan latihan ini untuk mempertahankan keefektifannya.

Empat penelitian dengan Randomized controlled trials menunjukkan perbedaan yang bermakna untuk mengurangi inkontinencia urin diantara kelompok yang dilakukan latihan otot dasar panggul dan kelompok kontrol. Evidence tersebut menunjukkan bahwa pengembalian yang lebih awal inkontinensia urin didapatkan pada beberapa orang yang melakukan latihan otot dasar panggul sebelum dan sesudah Trans Uretral Resection Prostatectomy, sebelum dan sesudah radikal prostatectomy, dan setelah radikal prostatectomy.One Cochrane yang mereview 10 Randomized Controlled Trails menemukan bahwa penggunaan terapi konservetive pada laki - laki yang telah dilakukan radical prostatectomy dan merupakan level I evidence. Lima Randomized controlled trial dengan menggunakan latihan otot dasar panggul sebagai prinsip intervensi dalam review ini yang diidentifikasi dari sumber literatur dan didiskusikan. Dari literatur ditemukan penggunaan latihan otot dasar panggul sebelum dan sesudah radikal prostatectomy (Sueppel Carralee, 2001). Evidence menunjukkan bahwa peningkatan latihan otot dasar panggul dapat menguatkan sfinkter eksternal dan memperbaiki inkontinensia urin pada klien laki - laki. 
Laki - laki harus melakukan latihan otot dasar panggul sesegera mungkin begitu mengetahui akan dilakukan operasi prostat (Dorey Grace, 2005). Secepatnya setelah pembedahan, latihan otot dasar panggul dilakukan dengan hati - hati pada saat kateter masih terpasang. Pada saat kateter dilepas latihan otot dasar panggul dilakukan dengan lebih kuat. Latihan otot dasar panggul harus diajarkan secara individual untuk meyakinkan klien bahwa otot dasar panggul terangkat. Laki - laki dapat mendorong mempererat dan mengangkat otot dasar panggul untuk mengontrol flatus dan aliran urin serta dipraktekkan di depan cermin.

Berdasar observasi yang dilakukan di lapangan, tindakan keperawatan latihan otot dasar panggul masih jarang diaplikasikan pada klien yang mengalami inkontinensia urin. Hal ini dapat disebabkan salah satunya karena perawat sendiri kadang belum memahami latihan otot dasar panggul. Tindakan keperawatan yang dilakukan untuk incontinencia urin berupa tindakan sederhana seperti menciptakan lingkungan yang memudahkan pasien untuk ke kamar mandi, meletakkan pispot atau urinal dalam jangkauan pasien, menganjurkan pasien untuk membiarkan lampu menyala di kamar tidur yang gelap, dan menasihati pasien agar memilih pakaian yang mudah ditanggalkan ketika ingin menggunakan kloset. Selain itu karena beban kerja dan kesibukan perawat yang menyebabkan tindakan tersebut kurang aplikatif. Perawat lebih mengedepankan tindakan - tindakan kolaboratif seperti injeksi, pemasangan infus, juga ada perawat yang masih mengerjakan tugas yang sebenarnya menjadi lingkup kegiatan administratif.

Tindakan ini ada beberapa tahapan yang harus dilaksanakan, untuk mendapatkan hasil yang baik diperlukan kesabaran dan waktu yang cukup lama bahkan ada yang hingga sampai satu tahun. Latihan ini masih tetap perlu untuk dilanjutan meskipun klien sudah pulang dari rumah sakit. Dalam kondisi seperti ini kadang klien tidak melanjutkannya karena tidak ada yang memotivasi, atau bisa juga klien mengalami kejenuhan, atau bahkan lupa akan rutinias yang harus dilakukan. Ketepatan klien dalam melakukan gerakannya atau langkah-langkahnya kadang juga sulit untuk dimonitor.

Patofisiologi dapat berubah berhubungan dengan incontinence dengan penyebab yang spesifik dari kelainannya. Dalam stress incontinence, peningkatan tekanan vesika sering dikarenakan beberapa aktivitas seperti bersin, batuk, tertawa atau aktivitas yang berat (Black, J.M.\&Hawks, 2005). Dysfungsi sfinkter uretra atau pada wanita berubah dalam sambungan uretra dan vesika yang disebabkan kelemahan otot periuretral. Kelemahan otot dapat terjadi akibat kelahiran anak, menopause atau masalah lain. Pada laki - laki patofisiologi berubah biasanya karena BPH yang dapat menyebabkan retansi, overflow dan stress inkontinensia. Detrusor overactivity (urge incontinence) dihubungkan dengan beberapa perubahan patofisiologi dan dalam beberapa kasus, patofisiologi tidak diketahui. Overflow urinary incontinence berakar dari regangan yang berlebihan pada kandung kemih dan volume urin yang berlebih. Biasanya disebabkan sumbatan pada pintu keluar kandung kemih (Black, J.M.\&Hawks, 2005).

Latihan otot dasar panggul meliputi mengencangkan otot -otot yang digunakan untuk menghentikan flatus atau aliran urin selama 5 sampai 10 detik, kemudian ditingkatkan, selanjutnya istirahat selama 10 detik. Untuk efektifitas latihan ini perlu untuk dilaksanakan 2 atau 3 kali sehari sampai paling tidak selama 6 minggu (Smeltzer, S.C., 2009). Tergantung pada kekuatan otot dasar 
panggul, saat dilakukan evaluasi awal latihan otot dasar panggul diulangi 10 sampai 20 kali pada setiap sesi. Pasien dengan usia lanjut memerlukan latihan yang lebih panjang untuk menguatkan otot-otot dasar panggul.

Mekanisme kontraksi dan meningkatkan tonus otot polos dinding kandung kemih dapat terjadi karena adanya rangsang pada otot polos kandung kemih sebagai dampak dari latihan. Latihan ini dapat menimbulkan rangsangan sehingga meningkattkan aktivasi dari kimiawi, neuromuskuler dan muskuler. Otot polos kandung kemih mengandung filamen aktin dan miosin yang mempunyai sifat kimiawi dan saling berinteraksi. Proses interaksi diaktifkan oleh ion kalsium dan adenotriposfat ( ATP ) selanjutnya dipecah menjadi adenodifosfat ( $A D$ ) untuk memberikan energi bagi konstraksi muskulus detrussor kandung kemih. Rangsangan melalui neuromuskuler akan meningkatkan rangsangan pada serat saraf otot polos kandung kemih terutama saraf parasimpatik yang merangsang produksi asetil cholin sehingga mengakibatkan terjadinya kontraksi. Mekanisme melalui muskulus, terutama otot polos kandung kemih akan meningkatkan metabolisme mitokondriauntuk menghasilkan ATP yang dimanfaatkan oleh otot polos kandung kemih sebagai energi untuk kontraksi dan meningkatkan tonus otot polos kandung kemih. Frekwensi latihan sangat bergantung dari jenis latihan yang diberikan dan optimalisasi sangat ditentukan oleh benar atau tidaknya gerakan yang dilakukan. Latihan dilakukan sampai klien mencapai konrol berkemih. Klien diinstuksikan untuk berkemih secepatnya bila merasakan keinginan untuk berkemih. Proses untuk mencapai kontrol berkemih adalah proses secara bertahap(Nursalam, 2006).

Latihan dasar otot panggul yang bermanfaat untuk membantu mengatasi gangguan eliminasi urin perlu untuk medapatkan perhatian perawat agar dapat memberikan dampak positip bagi klien. Perawat perlu menggunakan pendekatan proses keperawatan dalam memberikan asuhan yang meliputi pengkajian, diagnosa keperawatan, perencanaan, pelaksanaan dan evaluasi.

Diawali dengan perawat melakukan pengkajian dengan menanyakan pada klien mengenai pola berkemih harian termasuk frekwensi, waktu, volume normal urin yang dikeluakan setiap kali berkemih setelah klien dilakukan operasi. Pengkajian fisik memungkinkan perawat memperoleh data untuk menentukan keberadaan dan tingkat keparahan pada masalah eliminasi urin. Organ utama yang ditinjau kembali meliputi kulit, ginjal, kandung kemih dan uretra. Perawat juga mengkaji urin yang meliputi warna, jumlah, kejernihan, bau. Pengkajian fungsi eliminasi urin klien yang dilakukan terus - menerus menunjukkan pola data yang memungkinkan perawat membuat diagnosa keperawatan yang relevan dan akurat. Perawat berfikir secara kritis dengan merefleksikan pengetahuannya tentang klien sebelumnya, meninjau kembali karakteristik penentu yang teridentifikasi, menerapkan pengetahuan tentang fungsi urin dan kemudian membuat diagnosa keperaatan yang spesifik.

Setelah menegakkan diagnosa keperawatan perawat mengembangkan suatu rencana keperawatan, menetapkan tujuan dan hasil akhir yang diharapkan untuk setiap diagnosa. Rencana menggabungkan aktivitas untuk meningkatkan kesehatan dan intervensi terapiutik untuk klien yang mengalami masalah eliminasi urin. Pada klien post operasi prostatektomy untuk memenuhi kebutuhan eliminasi urin dilakukan pemasangan kateter. Selama kateter urin terpasang perawat perlu untuk melakukan 
observasi apakah aliran urin lancar, warna urin, jumlah urin yang tertampung. Perawat perlu mengobservasi selang - selang drainase dan mengirigasi sistem sesuai dengan yang diharuskan dan untuk menghilangkan segala bentuk obstruksi yang dapat menyebabkan ketidaknyamanan. Perawat juga mengobservasi abdomen bagian bawah untuk memastikan bahwa kateter tidak tersumbat. Kandung kemih yang penuh akan tampak bengkak membulat jelas di atas pubis. Kantong drainase, balutan dan letak insisi juga diperiksa terhadap perdarahan. Tekanan darah, nadi dan pernapasan dipantau dan dibandingkan dengan nilai dasar tanda - tanda vital pra operasi untuk mendeteksi hipotensi. Perawat mengobservasi adanya perilaku gelisah, keringat dingin, pucat dan setiap penurunan tekanan darah dan peningkatan frekwensi nadi. Selama kateter urin terpasang otot detrusor kandung kemih tidak secara aktif mengkontraksikan dinding kandung kemih pada proses pengosongan urin. Hal ini disebabkan urin mengalir keluar melalui kateter secara terus - menerus sehinggga detrusor tidak dapat segera merespon untuk mengosongkan kandung kemih ketika kateter dilepas. Perawat dapat mengajarkan pada klien tehnik pelaksanaan latihan otot dasar panggul dan memotivasi klien untuk aktif melakukannya karena tindakan ini membutuhkan waktu yang relatif lama untuk mencapai hasil yang diharapkan.

Di samping beberapa kelebihan yang dimiliki oleh latihan dasar otot panggul ada juga beberapa kendala yang dapat dijumpai terkait dengan pelaksanaannya. Klien harus mengetahui bahwa pencapaian kembali kontrol berkemih adalah proses bertahap. Klien harus menyadari dan termotivasi untuk melakukan latihan. Klien harus melanjutkan penggunaan latihan ini untuk mempertahankan keefektifannya. Untuk mendapatkan hasil seperti yang diharapkan latihan yang dilakukan harus tepat, sehingga pada awal mengajarkan pada klien perawat harus menjelaskan dengan sejelas mungkin dan memastikan persepsi klien seperti apa yang dimaksud oleh perawat. Sehingga dalam pelaksanaan latihan ini observasi dan evaluasi penting untuk dilakukan untuk memantau perkembangan klien. Latihan ini memerlukan ketepatan untuk pelaksanaannya sehingga bisa dikombinasikan antara latihan otot dasar panggul dengan terapist yang lebih memberikan keuntungan daripada menggunakan metode latihan otot dasar panggul sendirian. Untuk kondisi seperti ini di mana klien tidak bisa melakukannya sendiri sehingga membutuhkan bantuan terapist yang akan membutuhkan biaya.

Perawat spsesialist memegang peranan penting dalam upaya membantu klien dengan inkontinensia urin untuk mengembalikan fungsi sistem perkemihan yang salah satu tindakan keperawatan yang dapat dilakukan adalah melakukan latihan otot dasar panggul. Perawat klinik spesialist adalah perawat ahli di klinik yang memfokuskan pada perkembangan asuhan keperawatan. Perawat klinik spesialist adalah ahli klinik dan merupakan advokad klien dalam sebagian spesialist atau subspesialist dalam praktek keperawatan (Henderson Sharon, 2004). Tingkat master adalah masuk level untuk praktek untuk perawat klinik spesialis. Ada banyak peran perawat klinik spesialis yaitu sebagai pendidik, praktek klinik langsung, penelitian, konsultan dan administrasi.

Dalam peran sebagai pendidik, perawat klinik spesialist, tugas perawat termasuk mengembangkan, melaksanakan dan mengevaluasi sumber - sumber untuk klien dan keluarga, mengkoordinasi orientasi perawat, menyediakan program edukasi untuk masyarakat, mengevaluasi kemempuan perawat, menyediakan sertifikat kursus. Perawat klinik spesialis juga mengkoordinasi orientasi 
perawat yang baru lulus dan membimbingnya. Dalam hal latihan otot dasar panggul, sebagai perawat klinik spesialis memegang peranan penting untuk perannya sebagai pendidik yaitu mengembangkan, melaksanakan serta mengevaluasi sumber - sumber untuk klien dan keluarga dalam upaya melaksanakan latihan otot dasar panggul, menyediakan edukasi untuk latihan otot dasar panggul untuk masyarakat, perawat spesialis mengkoordinasi orientasi perawat dan membimbing termasuk tindakan untuk mengembalikan fungsi berkemih klien post op prostatectomy.

Perawat spesialis klinik keperawatan medikal bedah melakukan praktek klinik langsung sebagai perawat klinik ahli dan pelaksana. Termasuk di dalamnya adalah mengumpulkan informasi dan mensetting prioritas perawatan, menerapkan metode baru dalam perawatan, terapi modalitas dan mengevaluasi dan merencanakan perawatan individu. Perawat klinik spesialis termasuk bertugas melakukan pengkajian riwayat dan pemeriksaan fisik, order lab dan order pemeriksaan diagnostik. Perawat klinik spesialis mempunyai kewenangan memberikan petunjuk atau mungkin juga pemesanan pengobatan.

Sebagai peneliti, perawat klinik spesialist mempunyai tugas termasuk menerapkan hasil-hasil penelitian, mengajarkan perawat untuk melakukan kritik dan evaluasi hasil penelitian keperawatan dan medis. Perawat klinik spesialis berkonsultasi dengan perawat administrasi dan manager untuk mengembangkan dan melaksanakan kebijakan dan prosedur, klinikal pathways, standart perawatan, dan protap. Di luar rumah sakit perawat klinik spesialis mungkin juga sebagai konsultan pada kebijakan perawatan kesehatan dan legislation. Perawat klink spesialist dalam administrasi berespon terhadap program pengembangan dan mengevaluasi penampilan staf keperawatan. Beberapa perawat klinik spesialist dalam beberapa keadaan juga sebagai manager yang ditambahkan untuk menghantarkan audit keperawatan, mengumpulkan dan menyiapkan laporan aktivitas perawatan klien.

Pada akhirnya dengan kehadiran perawat spesialis diharapkan dapat membantu klien post prostatectomy yang mengalami inkontinensia urin untuk menguangi keluhannya dengan mengaplikasikan latihan otot dasar panggul. Untuk efektivitas latihan perawat mengembangkan dengan menggunakan pendekatan klinikal pathways dan membuat protap untuk memudahkan pelaksanaannya. Klien harus melakukan latihan otot dasar panggul segera setelah mengetahui akan dilakukan operasi. Secepatnya setelah operasi saat kondisi klien memungkinkan latihan otot dasar panggul boleh dilaksanakan meskipun klien masih terpasang kateter, dengan persetujuan dokter yang melakukan operasi.

Saat kateter dilepas, latihan otot dasar panggul dilakukan dengan lebih kuat. Lama waktu pelaksanaan latihan otot dasar panggul berkisar antara 3 minggu sampai 12 minggu. Semua latihan menekankan pentingnya latihan secara teratur di rumah. Pada minggu pertama klien sudah dapat merasakan hasilnya yaitu berkurangnya keluhan yang dirasakan. Latihan yang dilakukan meliputi mengencangkan otot -otot yang digunakan untuk menghentikan flatus atau aliran urin selama 5 sampai 10 detik, kemudian ditingkatkan, selanjutnya istirahat selama 10 detik. Untuk efektifitas latihan ini perlu untuk dilaksanakan 2 atau 3 kali sehari sampai paling tidak selama 6 minggu 
(Smeltzer, S.C., 2009). Tergantung pada kekuatan otot dasar panggul, saat dilakukan evaluasi awal latihan otot dasar panggul diulangi 10 sampai 20 kali pada setiap sesi.

Individu akan mendapatkan pengetahuan dan ketrampilan yang dialami orang lain dengan melalui observasi pada orang lain dan dengan mudah melalui pengaruh verbal atau melalui pengalaman. Latihan otot dasar panggul akan lebih baik dipelajari melalui proses kelompok. Dalam proses kelompok individu akan saling mempengaruhi, memberikan support dan saling memberikan motivasi. Belajar dalam kelompok juga menunjukkan bahwa support dalam kelompok dapat mengurangi stress dan meningkatkan motivasidan memberikan feedback selama interaksi. Hal ini akan sulit dilakukan apabila tidak terbentuk satu kelompok yang dapat mengefektifkan latihan otot dasar panggul, sehingga dengan melakukan latihan dalam kelompok diharapkan latihan dasar otot panggul akan semakin efektif untuk membantu klien mengatasi masalah inkontinensia urin(Zhang, 2007).

\section{KESIMPULAN}

1. Inkontinensia suatu kondisi di mana terjadi kehilangan urin tanpa disengaja melalui meatus uretra yang dapat berakibat pada masalah sosial dan kebersihan yang dapat diobservasi

2. Latihan otot dasar panggul dapat memperbaiki kemampuan berkemih dengan resiko yang lebih kecil.

3. Perawat spsesialist memegang peranan penting dalam upaya membantu klien dengan inkontinensia urin untuk mengembalikan fungsi sistem perkemihan yang salah satu tindakan keperawatan yang dapat dilakukan adalah melakukan latihan otot dasar panggul.

\section{DAFTAR PUSTAKA}

Black, J.M.\&Hawks, J. H. (2005). Medikal Surgical Nursing Clinical Managemen for Positive Outcome (8th ed.). St. Louis: Elsevier.

Dorey Grace. (2005). Restoring pelvic floor function in man : review of RCTs.

Henderson Sharon. (2004). The role of clinical nurse specialist in medical surgical nursing.

Munn Zachary. (2008). Urinary incontinence: Pelvic floor training. Retrieved from http//proquest.umi.com/pqdweb?did1516584201\&sid=11\&fmt=3\&clentld=45625\&RQT=309.7 VName=PQD

nursalam. (2006). Asuhan Keperawatan Klien dengan Gangguan Sistem Perkemihan. Jakarta: Salemba Medika.

Smeltzer, S.C., \& B. B. . (2009). Texbook of medikal Surgical Nursing (11th ed.). Philladelphia: Lipincott Williams \& Wilknis.

Sueppel Carralee. (2001). Improved Continence Outcomes with preoperative pelvic floor muscle strengthening exercise.

Zhang, A. Y. (2007). Effect of combined pevic floor exercise and a support group on urinary incontinence and quality of live of prostatectomy patient. 